\title{
The isolation and characterisation of a major outer- membrane protein from Bacteroides distasonis
}

\author{
HANNAH M. WEXLER* ${ }^{*}, C$. GETTY* and G. FISHER* \\ "Research Service, VA Wadsworth Medical Center, Los Angeles, CA 90073 and † Department of Medicine, \\ University of California, Los Angeles, CA 90024, USA
}

\begin{abstract}
Summary. An outer-membrane protein (OMP) was isolated from a clinical strain of Bacteroides distasonis. Changes in growth media did not appreciably affect the appearance of this protein in crude outer-membrane preparations examined by SDS-PAGE. However, the proportion of the protein relative to other OMPs was greater in 24-h cultures than in 48-h cultures. The protein could not be readily solubilised by various conventional detergent extraction techniques but treatment of the insoluble material at $100^{\circ} \mathrm{C}$ with SDS released the protein, as did overnight extraction at $37^{\circ} \mathrm{C}$ with SDS. This OMP was heat-modifiable, and thus was similar to the OmpA protein of Escherichia coli, with a faster mobility on SDSPAGE when solubilised at $25^{\circ} \mathrm{C}$ than at $100^{\circ} \mathrm{C}$. The critical temperature for conversion was between $80^{\circ} \mathrm{C}$ and $90^{\circ} \mathrm{C}$. Because of the characteristic heat-modifiability, the protein was called $B$. distasonis HMP-1 (heat modifiable protein-1). Overnight exposure to EDTA or $\mathrm{NaCl}$ at $37^{\circ} \mathrm{C}$ favoured conversion of the $25^{\circ} \mathrm{C}$ form to the $100^{\circ} \mathrm{C}$ form. In intact cells, the protein was labelled by a cell-surface radio-iodination procedure, and thus is at least partially exposed at the cell surface. No reactions between the $B$. distasonis HMP-1 and antibodies to either E. coli OmpA or E. coli porin were found by Western blot analysis. A B. distasonis OM preparation containing predominantly HMP-1 had pore-forming ability in a liposome assay. This study is the first report of the isolation and characterisation of a heat-modifiable OMP in Bacteroides, and it is the first description of pore-forming activity in a Bacteroides OM fraction.
\end{abstract}

\section{Introduction}

The structure and function of outer-membrane proteins (OMPs) in aerobic gram-negative bacteria has been studied extensively, and our understanding of their role in dynamic cell processes has increased. ${ }^{1-3}$ The pore-forming molecules of Escherichia coli and some other aerobic bacteria have been characterised, ${ }^{3-8}$ and their contribution to antimicrobial resistance assessed. ${ }^{8-16}$ Similar research in gram-negative anaerobes has been hampered by lack of knowledge about the structure-function characteristics of their OMPs.

Studies on the development of resistance to $\beta$-lactam antibiotics in anaerobic bacteria have focused on the production of $\beta$-lactamase enzymes. ${ }^{17-20}$ The Bacteroides fragilis group of organisms (Bacteroides sensu stricto) are amongst the anaerobes most frequently isolated from clinical infections, and are some of the most resistant to antimicrobial agents. ${ }^{21}$ The OMP profiles of members of the $B$. fragilis group are much more complex than those of $E$. coli, ${ }^{22,23}$ and specific permeability functions have not been assigned to any

Received 17 July 1991; revised version accepted 7 Nov. 1991. molecular species in Bacteroides. Recently, a few studies $^{18,24}$ described permeability of the bacterial cells to $\beta$-lactams as a factor in the activity of these agents against the $B$. fragilis group, especially for $B$. distasonis, ${ }^{24}$ which although one of the most resistant of the group, has one of the lowest proportions of $\beta$ lactamase-positive strains.

The purpose of this study was to investigate OMPs in $B$. distasonis and to describe the structure-function characteristics of the major OMPs. Additionally, we hoped to identify pore-forming proteins in this organism as a first step in assessing their role in resistance to $\beta$-lactam antibiotics.

\section{Materials and methods}

\section{Preparation of crude outer membrane}

B. distasonis Wadsworth Anaerobe Laboratory (WAL) strain 6779 was identified by standard methods ${ }^{25,26}$ and grown for $24 \mathrm{~h}$ in tryptone-yeastglucose (TYG) broth ${ }^{27}$ in an anaerobic chamber (Anaerobe Systems, Santa Clara, CA, USA). The cells were harvested by centrifugation at $12000 \mathrm{~g}$ for $20 \mathrm{~min}$ 
in a Sorvall RC-5B centrifuge, and washed once in $10 \mathrm{~mm}$ Tris- $\mathrm{HCl}$ containing $10 \mathrm{mM} \mathrm{MgSO}_{4}, \mathrm{pH} \mathrm{7 \cdot 4}$. The harvested cells were then broken by four passages through a French Pressure Cell (SLM Instruments, Urbana, IL, USA) at $12000 \mathrm{lb} / \mathrm{in}^{2}$. The suspension was centrifuged at $2000 \mathrm{~g}$ for $5 \mathrm{~min}$ to remove whole cells and cell debris. The supernate contained the cell envelopes. In general, $4 \mathrm{~L}$ of overnight cell culture were processed and eventually resuspended to yield $108 \mathrm{ml}$ of cell-envelope preparation.

Inner membrane was solubilised by adding to the cell envelope preparation, Triton X-100 2\% v/v, $10 \mathrm{mM} \mathrm{MgCl}_{2}$, and $10 \mathrm{~mm}$ HEPES (final concentrations). The mixture was incubated for $30 \mathrm{~min}$ at room temperature, and then centrifuged at $45000 \mathrm{~g}$ for $1 \mathrm{~h}$ in a Sorvall RC-5B centrifuge. The resulting pellet containing the crude outer membrane (OM) was washed once with $10 \mathrm{~mm}$ Tris- $\mathrm{HCl}, 10 \mathrm{~mm} \mathrm{MgSO}$,

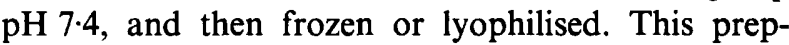
aration is referred to as $B$. distasonis crude OMP.

\section{Isolation of $B$. distasonis $H M P-1$}

The crude OMP (64 mg) was resuspended in $50 \mathrm{ml}$

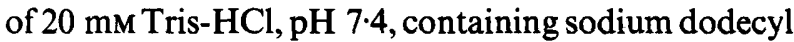
sulphate (SDS) $0.7 \% \mathrm{w} / \mathrm{v}$, incubated for 15-30 min at $30^{\circ} \mathrm{C}$, and then centrifuged at $100000 \mathrm{~g}$ (Beckman L565 Ultracentrifuge, Beckman Instruments, Fullerton, CA, USA) for $2 \mathrm{~h}$. The pellet, containing the partially purified protein, was washed once with $20 \mathrm{mM}$ Tris-

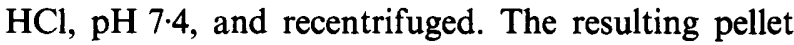
(SDS pellet) was extracted with $4 \mathrm{ml}$ of octyl-glucoside (OG; Pierce Chemical Co., Rockford, IL, USA) $3.5 \%$ $\mathrm{w} / \mathrm{v}$ in $20 \mathrm{~mm}$ Tris- $\mathrm{HCl}, \mathrm{pH} 7 \cdot 4$, overnight at $30^{\circ} \mathrm{C}$, and for an additional $1-2 \mathrm{~h}$ at $37^{\circ} \mathrm{C}$. The mixture was centrifuged at $100000 \mathrm{~g}$ and the supernate was dialysed in $20 \mathrm{mM}$ Tris- $\mathrm{HCl}, \mathrm{pH} 7 \cdot 4$, for $24-48 \mathrm{~h}$ at $4^{\circ} \mathrm{C}$ with frequent changes of buffer. The protein migrating at $45 \mathrm{kDa}$ after solubilisation at $100^{\circ} \mathrm{C}$ was designated as $B$. distasonis HMP-1 because of its unusual heatmodifiable migration patterns on SDS-PAGE (see below). The dialysed preparation was concentrated $c$. four-fold with a Centricon-10 microconcentrator (Amicon, Danvers, MA, USA) and frozen at $-70^{\circ} \mathrm{C}$. This preparation was used for the liposome assay below.

\section{Protein assays}

The SDS-pellet and octyl-glucoside supernate preparations were first assayed with the BioRad protein assay kit (BioRad Laboratories, Richmond, CA, USA) and the Sigma protein assay kit (Sigma Diagnostics, St Louis, MO, USA). However, resulting concentrations seemed much lower than those estimated by comparing band densities on SDS-PAGE gels to band densities of bovine serum albumin standards. The $B$. distasonis HMP-1 protein was finally assayed by amino-acid analyses and by the BCA protein assay kit (Pierce Chemical Co.). With the amino-acid analysis as the standard, a "conversion factor" was established that was subsequently used to convert the Pierce assay results to a more precise protein measurement.

\section{$S D S-P A G E$}

Proteins were subjected to SDS-PAGE in a modified Laemmli gel $^{28}$ with an acrylamide : bis acrylamide ratio of $30: 0.8$ and an acrylamide concentration of $10 \%$ $\mathrm{w} / \mathrm{v}$ for the running gel, and an acrylamide:bis acrylamide ratio of $30: 1 \cdot 0$ and an acrylamide concentration of $4 \% \mathrm{w} / \mathrm{v}$ for the stacking gel. Mol. wts were determined from standard curves constructed with mol.-wt standards (BioRad) by linear regression analysis with Symphony 2.0 statistical applications (Lotus Development Corporation, Cambridge, MA, USA).

\section{Electro-elution of the HMP-1 molecule}

SDS pellets were run on SDS-PAGE gels as indicated above but not stained. Two end lanes were cut out from the gel and bands were visualised after incubation in ice-cold $0.25 \mathrm{M} \mathrm{KCl}$ for $10 \mathrm{~min}$ to precipitate the proteins. ${ }^{29}$ The remainder of the gel was untreated. The two end lanes served as reference lanes for cutting the appropriate bands for electro-elution, which was accomplished with a Model 422 ElectroEluter (BioRad) following the manufacturer's directions.

\section{Electroblotting of the HMP-1 molecule}

SDS-PAGE gel solutions were filtered through a Nalgene $45-\mu \mathrm{m}$ filter (Nalge Company, Rochester, NY, USA) immediately before pouring. Gels were stored for $24 \mathrm{~h}$ at room temperature and run as indicated above. Electroblotting was accomplished with a Trans-blot cell (BioRad) on to PVDF Protein Sequencing Membrane (BioRad) and stained according to the manufacturer's directions.

\section{Amino-acid analysis of the HMP-1 molecule}

Amino-acid analysis was performed by Dr Audrey Fowler at the University of California Protein Microsequencing Facility, Los Angeles, CA, by the Pico-Tag system (Walters/Millipore Corp., Bedford, MA, USA) after hydrolysis in $6 \mathrm{~N} \mathrm{HCl}$ of electro-eluted preparations of the HMP-1 molecule transferred to BioRad PVDF protein sequencing membrane. The ratio of polar to apolar amino acids was calculated according to the method of Hatch, ${ }^{\mathbf{3 0}}$ and the polarity index according to the method of Capaldi and Vanderkooi. ${ }^{31}$

Western blot analysis of the B. distasonis outer membrane

Anti-E. coli OmpA antiserum was obtained from $\mathrm{Dr}$ 
P. J. Bassford (University of North Carolina, Chapel Hill, NC, USA). This antiserum had been prepared in rabbits against purified OmpA. The anti-E. coli porin was obtained from Dr S. C. Rittenberg (University of California, Los Angeles, CA, USA) and had been prepared in the laboratory of $\mathrm{Dr} \mathrm{H}$. Nikaido (University of California, Berkeley, CA, USA) in rabbits against purified porin. Western blot analysis was performed as described previously, ${ }^{32}$ with dilutions of 1 in 250 of the respective antibody preparations.

\section{Radio-iodination}

Bacteria from 12-h cultures were washed twice with

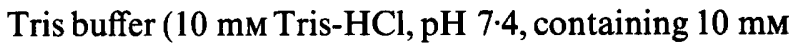
$\mathrm{MgSO}_{4}$ ) and resuspended to $0.2 \mathrm{~g} / \mathrm{ml}$ (wet weight). Iodo-beads (Pierce Chemical Co.) were washed and dried according to the manufacturer's instructions. Tris buffer $100 \mu \mathrm{l}$, carrier-free $\mathrm{Na}^{125}$ (Amersham, Arlington Heights, IL, USA $500 \mu \mathrm{Ci}(5 \mu \mathrm{l})$ and five Iodo-beads were added to a $20 \mathrm{~mm} \times 125 \mathrm{~mm}$ glass tube and held for $5 \mathrm{~min}$ at room temperature; $1 \mathrm{ml}$ of the cell suspension was added to the glass tube and the radio-iodination reaction was allowed to proceed for $15 \mathrm{~min}$ at room temperature with occasional gentle swirling. Radio-iodination was terminated by removing the Iodo-beads from the reaction mixture. The ${ }^{125} \mathrm{I}$ labelled cells were washed three times with $20 \mathrm{ml}$ of Tris buffer to remove unreacted ${ }^{125} \mathrm{I}$, as well as any extraneous proteins that may have been released from lysed cells, and processed as described above to obtain OM. Samples of crude cell lysate, crude OM, and SDS pellet were removed for autoradiography.

\section{Autoradiography}

SDS-PAGE gels were stained with Coomassie Blue R250, dried on filter paper, and exposed to Kodak XOmat XAR-5 film at room temperature for $12 \mathrm{~h}$.

\section{Reconstitution of pore-forming activity in liposomes and liposome swelling assay}

Phosphatidyl choline was purified ${ }^{7}$ from crude egg yolk phosphatidyl choline (Sigma) and stored at $-70^{\circ} \mathrm{C}$. Liposomes were prepared by the procedure of Nikaido and Rosenberg. ${ }^{7,33}$ Briefly, $2.4 \mu \mathrm{mol}$ of $\mathrm{L}-\alpha-$ phosphatidyl choline and $0.1 \mu \mathrm{mol}$ of dicetyl phosphate were added to a round-bottom glass tube and dried with a gentle stream of $\mathrm{N}_{2}$. The dried lipids were washed with $100 \mu \mathrm{l}$ of benzene, dried, and then washed with $100 \mu \mathrm{l}$ of ethyl ether and dried again. The tubes were then stored overnight under vacuum in a desiccator jar in the dark. The desired amount of protein (dissolved in water) was added to the tubes, and the tubes were sonicated in an ultrasonic water bath (L and R Manufacturing Co., Kearny, NJ, USA) until the solution became translucent. The preparations were dried under vacuum and kept in an evacuated jar in the dark for $45 \mathrm{~min}$. A solution of Dextran T-40
(Pharmacia, Piscataway, NJ, USA) $15 \% \mathrm{w} / \mathrm{v}$ in $5.0 \mathrm{~mm}$ Tris- $\mathrm{HCl}, \mathrm{pH} 7.5$, was added, and the lipid layer was wetted evenly. After incubation for $45 \mathrm{~min}$ at room temperature, the tubes were shaken briskly by hand to resuspend the liposomes. Liposomes with no protein added or with heat-treated protein or $E$. coli $\mathrm{K} 12$ crude OMP were used as controls. The liposome swelling assays were done as described by Nikaido and Rosenberg $^{7}$ with a Beckman Model 35 Spectrophotometer. Iso-osmolar sugar solutions $(c .0 \cdot 1 \mathrm{M})$ were prepared with an osmometer (Advanced Digimatic Osmometer Model 30-II, Advanced Instruments, Needham Heights, MA, USA). Rates of permeability were measured by $\mathrm{d}(1 / \mathrm{OD}) / \mathrm{dt}$, according to the method of Nikaido. ${ }^{35}$

\section{Results}

\section{Isolation of the B. distasonis HMP-1 protein}

Initial attempts to purify the $B$. distasonis HMP-1 molecule indicated that the proportion of this protein relative to the other OMPs of similar mol. wt was not consistent when crude OM from different batches was compared in SDS-PAGE. To try to standardise the proportions of the various components formed, the OMP profiles of $B$. distasonis grown in different media, including Brucella broth (Difco), Anaerobe broth (Difco) and the TYG described above, were studied. No major differences were seen in the proportions of HMP-1. However, the proportion of HMP-1 relative to the other components in the extraction mixture was greater in a $24-\mathrm{h}$ culture than in a 48 -h culture. These conditions (i.e. incubation for $24 \mathrm{~h}$ in TYG broth) for growing the cells were then followed for the remainder of the study.

When harvested cells were broken in a French Pressure Cell and treated with Triton X-100 to remove the inner membrane, ${ }^{35,36}$ the HMP-1 component remained in the Triton pellet. Because of earlier reports that porin protein from other bacterial species was SDS-insoluble, ${ }^{37}$ this pellet was treated with various concentrations of SDS $(0.5-2.5 \% \mathrm{w} / \mathrm{v})$ at $30^{\circ} \mathrm{C}$ to remove some of the contaminating proteins. Selective extraction of the crude OMP (Triton pellet) for either the HMP-1 protein or other contaminating proteins was also attempted with other detergents including sodium deoxycholate, Zwittergent, Nonidet, and Sarkosyl. SDS $0.7 \% \mathrm{w} / \mathrm{v}$ was the most efficient at selectively removing the contaminating proteins from the Triton pellet. Low concentrations extracted small amounts of the contaminating proteins, whereas high concentrations extracted many other proteins along with the HMP-1.

Solubilisation of the HMP-1 protein from the SDS pellet was first attempted with high salt $(0.4 \mathrm{M} \mathrm{NaCl})$, according to the procedure of Mitsuyama et al., ${ }^{37}$ but without EDTA and $\beta$-mercaptoethanol, because adding both of those components changed the distinctive heat-modifiable electrophoretic behaviour of 
the $B$. distasonis HMP-1. Solubilisation with high salt was not successful. The procedure described by Hancock et al. ${ }^{38}$ to extract the porin of Pseudomonas aeruginosa with a Triton X-100, EDTA solution was also attempted; no proteins were extracted from our preparation by this method. Two detergents, Chapso (Sigma) and OG, were then examined for their ability to extract the HMP-1 component. OG was the best detergent for extracting the HMP-1 from the SDS pellet, and it had the added advantage of being a small molecule $(289 \mathrm{Da})$ which was easily removed by dialysis. A concentration of $3.5 \% \mathrm{w} / \mathrm{v}$ resulted in the best yield, although some HMP-1 remained in the insoluble pellet. Further overnight extractions at $30^{\circ} \mathrm{C}$ of the OG-insoluble pellet with either OG $5 \% \mathrm{w} / \mathrm{v}$ or SDS $2 \% \mathrm{w} / \mathrm{v}$ were also attempted, but did not yield significant additional amounts of HMP-1 protein. SDS-PAGE patterns of samples of various stages of the purification are shown in fig. 1. All samples run on SDS-PAGE throughout this study were solubilised at both $25^{\circ} \mathrm{C}$ and $100^{\circ} \mathrm{C}$ to detect the distinctively migrating HMP-1 band. The protein was fully released from the SDS-insoluble material by boiling the sample or by overnight extraction at $37^{\circ} \mathrm{C}$ in $0.1 \mathrm{M}$ Tris- $\mathrm{HCl}$, $\mathrm{pH} 7 \cdot 4$, with SDS $2 \% \mathrm{w} / \mathrm{v}$ (see below).

\section{Heat modifiability of the $H M P-1$ protein}

The HMP-1 protein had a distinctive heat-modifiable electrophoretic mobility similar to that of the OmpA protein of $E$. coli which migrates more slowly when solubilised at $100^{\circ} \mathrm{C}$ than when solubilised at $25^{\circ} \mathrm{C}$. ${ }^{39}$ The $B$. distasonis HMP-1 band at $38 \mathrm{kDa}$ from preparations solubilised at $25^{\circ} \mathrm{C}$ was electro-eluted from an SDS-PAGE gel and then incubated at both $25^{\circ} \mathrm{C}$ and $100^{\circ} \mathrm{C}$ and re-run; the $25^{\circ} \mathrm{C}$ and $100^{\circ} \mathrm{C}$ preparations again migrated, respectively, to $38 \mathrm{kDa}$ and $45 \mathrm{kDa}$ (fig. 2). Electro-elution resulted in conversion, to some degree, of the $38-\mathrm{kDa}$ to the $45-\mathrm{kDa}$ form. However, maintaining all buffers and samples at $4^{\circ} \mathrm{C}$ minimised the extent of this conversion.

Fig. 3 shows an SDS-PAGE gel of the SDS pellet solubilised at various temperatures. The apparent mol. wt of the $B$. distasonis HMP-1 was $38 \mathrm{kDa}$ when solubilised at $25^{\circ} \mathrm{C}$, and $45 \mathrm{kDa}$ when solubilised at $100^{\circ} \mathrm{C}$. HMP -1 solubilised at $55^{\circ} \mathrm{C}$ showed the same pattern as that extracted at $25^{\circ} \mathrm{C}$, whereas the material solubilised at $80^{\circ} \mathrm{C}$ showed migration bands of both species, with the band at $38 \mathrm{kDa}$ predominating. The material solubilised at $90^{\circ} \mathrm{C}$ showed migration of both species, with the band at $45 \mathrm{kDa}$ predominating. The material solubilised at $100^{\circ} \mathrm{C}$ showed primarily the band at $45 \mathrm{kDA}$. Thus, the major shift from the 38 $\mathrm{kDa}$ form to the $45-\mathrm{kDa}$ form occurred between $80^{\circ} \mathrm{C}$ and $90^{\circ} \mathrm{C}$.

\section{Metal ion effects on $B$. distasonis HMP-1 migration on SDS-PAGE}

The dependence on metal ions of the SDS migration form of the $B$. distasonis HMP-1 protein was ex-

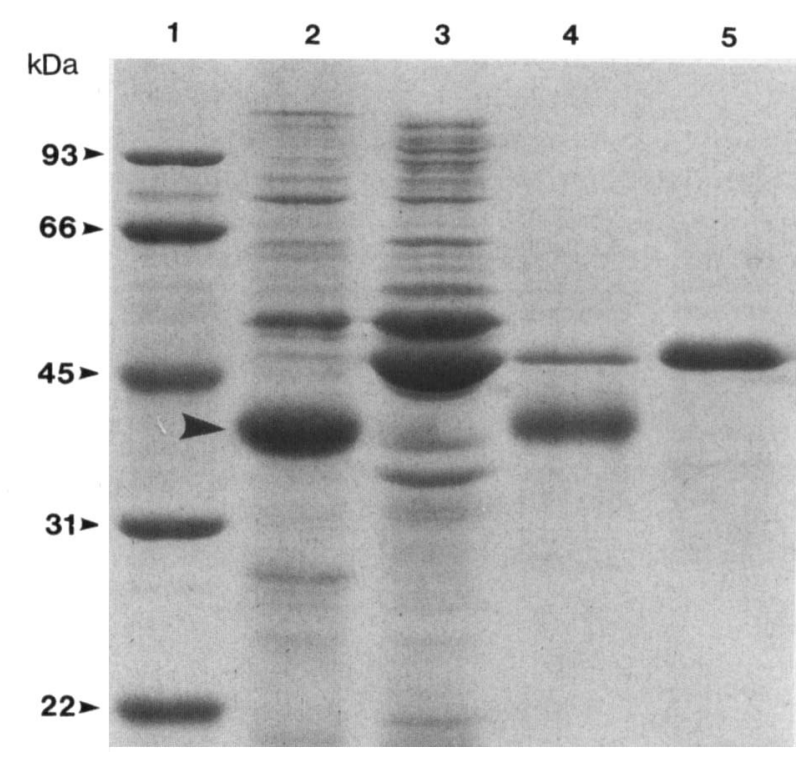

Fig. 2. SDS-PAGE patterns of $B$ distasonis HMP-1 preparations (electro-eluted, $25^{\circ} \mathrm{C}$ ): lane 1, low-mol.-wt standards; 2, SDS pellet (solubilised at $\left.25^{\circ} \mathrm{C}\right) ; 3$, SDS pellet $\left(100^{\circ} \mathrm{C}\right) ; 4$, electro-eluted $38-\mathrm{kDa}$ band cut from identical gel (as indicated by arrow) and solubilised at $25^{\circ} \mathrm{C} ; 5$, electro-eluted 38-kDa band cut from identical gel $(\rightarrow)$ and solubilised at $100^{\circ} \mathrm{C}$. Electro-eluted band was dialysed against $10 \mathrm{mM}$ Tris- $\mathrm{HCl}, \mathrm{pH} \mathrm{7 \cdot 4}$, and concentrated in a Centricon PM10 (Amicon).

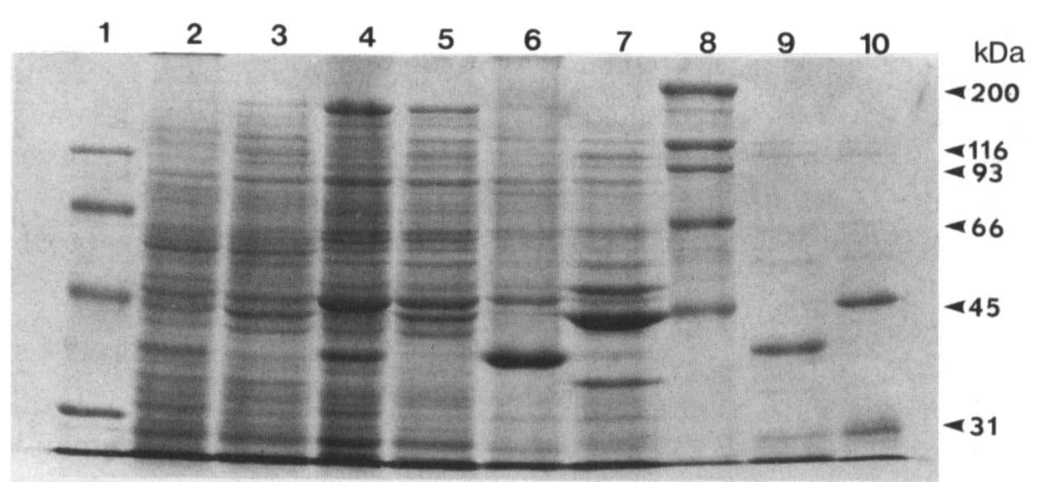

Fig. 1. SDS-PAGE gel of $B$. distasonis HMP-1 preparation: lane 1, low-mol.-wt standards; 2, cell envelope (solubilised at $25^{\circ} \mathrm{C}$ ); 3 , cell envelope $\left(100^{\circ} \mathrm{C}\right) ; 4$, Triton pellet (crude OMP) $\left(25^{\circ} \mathrm{C}\right) ; 5$, Triton pellet (crude OMP) $\left(100^{\circ} \mathrm{C}\right) ; 6$, SDS pellet $\left(25^{\circ} \mathrm{C}\right) ; 7$, SDS pellet $\left(100^{\circ} \mathrm{C}\right)$; 8, high-mol.-wt standards; 9 , octyl-glucoside supernate (OG-Sup) $\left(25^{\circ} \mathrm{C}\right) ; 10$, OG-Sup $\left(100^{\circ} \mathrm{C}\right)$. 


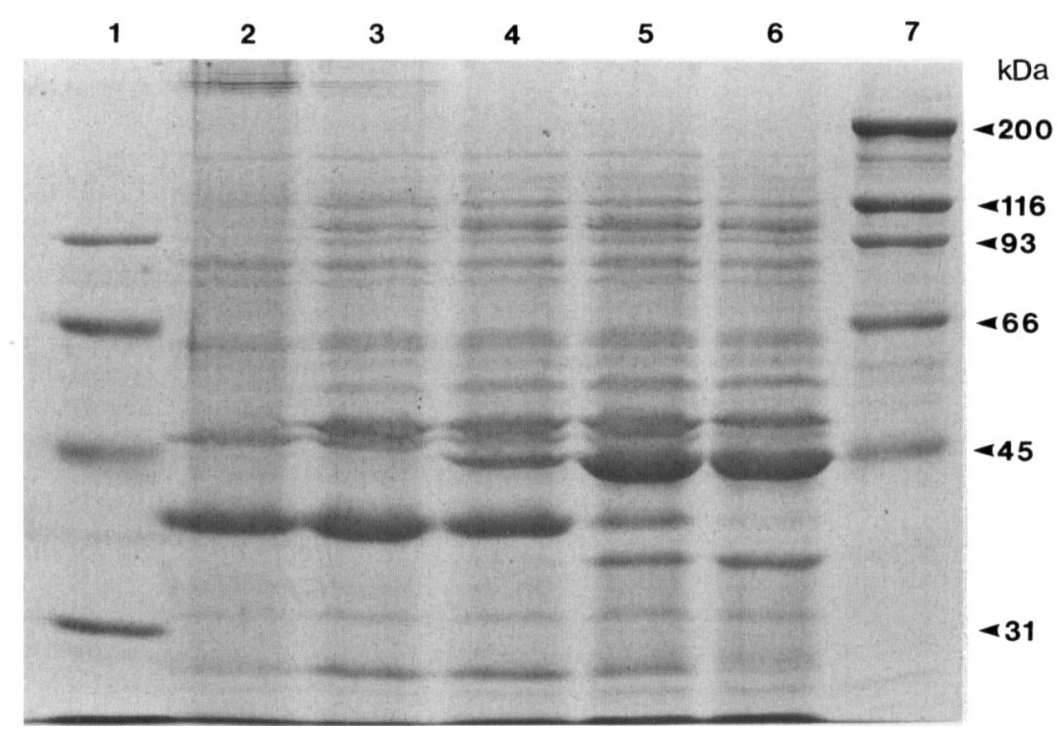

Fig. 3. Heat modifiability of the $B$. distasonis HMP-1 protein: SDS-pellet preparations were solubilised in sample buffer at the indicated temperatures before electrophoresis: lane 1 , low-mol.-wt standards; $2,25^{\circ} \mathrm{C} ; 3,55^{\circ} \mathrm{C} ; 4,80^{\circ} \mathrm{C} ; 5,90^{\circ} \mathrm{C} ; 6,100^{\circ} \mathrm{C} ; 7$, high-mol.-wt standards.

amined. In E. coli, the stability of the low-temperature form of OmpA appears to involve magnesium ions. ${ }^{40}$ Metal-ion-complexing reagents such as EDTA, phosphate ions, hydroxyl ions, the competitive cations $\mathrm{Zn}^{++}$or $\mathrm{Ca}^{++}$, or the reducing agent $\beta$-mercaptoethanol $(\beta$-ME) seems to cause nearly complete conversion of the $E$. coli protein to the high-mol.-wt (i.e., slower migrating) form. However, the addition of $\mathrm{NaCl}$ or magnesium ions favours the conversion to, or preservation of, the low-mol.-wt (i.e., faster migrating) form. In $B$. distasonis HMP-1, all of the protein migrated at the slower rate after solubilisation at $100^{\circ} \mathrm{C}$, whether or not the metal-ion-complexing or competing solutions $(\beta$-ME $10 \% \mathrm{v} / \mathrm{v}, 5.0 \mathrm{mM}$ EDTA, or $100 \mathrm{mM} \mathrm{CaCl}_{2}$ ) were added. In contrast to the results seen with $E$. coli $\mathrm{OmpA}, 300 \mathrm{~mm} \mathrm{NaCl}$ or $100 \mathrm{mM} \mathrm{MgCl}$ did not preserve or convert any of the high-mol.-wt form to the low-mol.-wt form.

The SDS pellet was incubated overnight at $37^{\circ} \mathrm{C}$ with: (1) Tris buffer; (2) Tris buffer with SDS $2 \% \mathrm{w} / \mathrm{v}$; (3) Tris buffer with SDS $2 \% \mathrm{w} / \mathrm{v}$ and $0.4 \mathrm{M} \mathrm{NaCl}$; or (4) Tris buffer with SDS $2 \% \mathrm{w} / \mathrm{v}$ and $10 \mathrm{~mm}$ EDTA . After recentrifugation, the samples incubated in Tris alone retained about half of the HMP-1 band in the pellet fraction, and the fractions solubilised at $25^{\circ} \mathrm{C}$ or $100^{\circ} \mathrm{C}$ migrated as expected. The samples incubated with Tris and SDS released nearly all of the HMP-1 into the supernate fraction. About half of this fraction solubilised at $25^{\circ} \mathrm{C}$ had converted to the $100^{\circ} \mathrm{C}$ form (fig. 4a). The samples extracted with Tris, SDS and $\mathrm{NaCl}$ released about half of the HMP-1 into the supernate fraction; all of the HMP-1 (solubilised at $25^{\circ} \mathrm{C}$ ) in both the supernate and pellet fractions migrated in the $100^{\circ} \mathrm{C}$ form. The sample extracted with Tris, SDS and EDTA released nearly all of the HMP1 into the supernate fraction except that nearly all of the protein solubilised at $25^{\circ} \mathrm{C}$ migrated as the $100^{\circ} \mathrm{C}$ form (fig. $4 b$ ). We concluded from these experiments that: (1) SDS was needed to fully release the $B$. distasonis HMP-1 from the pellet; (2) neither $\mathrm{NaCl}$ nor EDTA was necessary for full release of the HMP-1 ; (3) the addition of $\mathrm{NaCl}$ to the Tris and SDS seemed to inhibit full release of the protein; (4) prolonged exposure to EDTA or $\mathrm{NaCl}$ at $37^{\circ} \mathrm{C}$ favoured conversion of the $25^{\circ} \mathrm{C}$ form to the $100^{\circ} \mathrm{C}$ form.

\section{Amino-acid analysis of the HMP-1 protein}

Table I lists the amino-acid composition of the HMP-1 molecule in both $25^{\circ} \mathrm{C}$ and $100^{\circ} \mathrm{C}$ forms. The analysis was performed on an electro-eluted HMP-1 $38-\mathrm{kDa}\left(25^{\circ} \mathrm{C}\right)$ band that was then electrophoresed separately at $25^{\circ} \mathrm{C}$ and $100^{\circ} \mathrm{C}$ and transferred to blotting paper. The analysis was done on both the $25^{\circ} \mathrm{C}$ and $100^{\circ} \mathrm{C}$ bands to determine whether there were any obvious differences in amino-acid content between the two bands. No significant differences were seen. Tables II and III list the polarity and polarity index values of the $25^{\circ} \mathrm{C}$ and $100^{\circ} \mathrm{C}$ forms. The aminoacid composition of a heat-modifiable membrane protein from a Fusobacterium sp. $^{41}$ is included for comparison. Capaldi and Vanderkooi ${ }^{32}$ found that membrane proteins with polarities below $40 \%$ could generally be considered "intrinsic" membrane proteins and could be separated from their respective membranes only by detergents or organic solvents, whereas $85 \%$ of the soluble proteins studied had polarities of $47 \pm 6 \%$. The $B$. distasonis HMP-1 had a polarity of $43 \%$, indicating that at least portions of the molecule are likely to be intrinsic to the membrane. The relatively lengthy incubation necessary to release this protein from the SDS pellet supports this assumption. A low polarity index, according to Hatch, ${ }^{31}$ indicates compact molecules with a high content of helical structure which may form heterologous interactions with other apolar materials leading to in- 

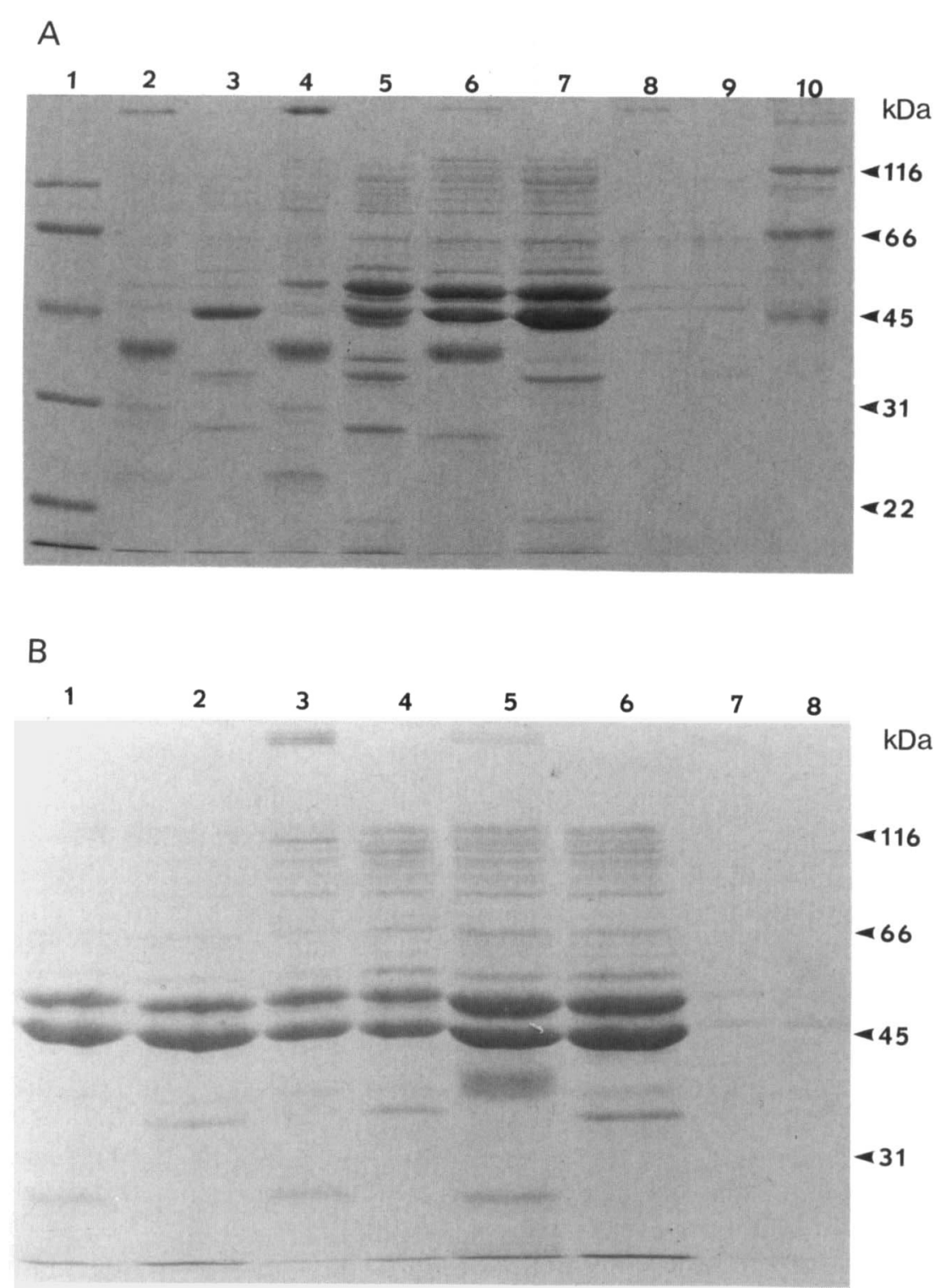

Fig. 4. SDS-PAGE patterns of proteins solubilised $\left(25^{\circ} \mathrm{C}\right.$ or $\left.100^{\circ} \mathrm{C}\right)$ from SDS pellet extracted overnight at $37^{\circ} \mathrm{C}$ with: (A) $10 \mathrm{mM} \mathrm{Tris-HCl}$, $\mathrm{pH} 7.4$, alone (lanes 2-5) or with SDS $2 \% \mathrm{w} / \mathrm{v}$ (lanes 6-9)-lane 1 , low-mol.-wt standards; 2 , supernate $\left(25^{\circ} \mathrm{C}\right) ; 3$, supernate $\left(100^{\circ} \mathrm{C}\right) ; 4$, pellet $\left(25^{\circ} \mathrm{C}\right) ; 5$, pellet $\left(100^{\circ} \mathrm{C}\right) ; 6$, supernate $\left(25^{\circ} \mathrm{C}\right) ; 7$, supernate $\left(100^{\circ} \mathrm{C}\right) ; 8$, pellet $\left(25^{\circ} \mathrm{C}\right) ; 9$, pellet $\left(100^{\circ} \mathrm{C}\right)$; 10 , high-mol.-wt standards; (B) $10 \mathrm{mM}$ Tris- $\mathrm{HCl}, \mathrm{pH} 7.4$, with SDS $2 \% \mathrm{w} / \mathrm{v}$ and $0.4 \mathrm{M} \mathrm{NaCl}$ (lanes 1-4) or $10 \mathrm{~mm}$ EDTA (lanes 5-8)-lane 1, supernate $\left(25^{\circ} \mathrm{C}\right) ; 2$, supernate $\left(100^{\circ} \mathrm{C}\right)$; 3 , pellet $\left(25^{\circ} \mathrm{C}\right) ; 4$, pellet $\left(100^{\circ} \mathrm{C}\right) ; 5$, supernate $\left(25^{\circ} \mathrm{C}\right) ; 6$, supernate $\left(100^{\circ} \mathrm{C}\right) ; 7$, pellet $\left(25^{\circ} \mathrm{C}\right) ; 8$, pellet $\left(100^{\circ} \mathrm{C}\right)$.

corporation of these proteins in to lipid-containing membranes. The $B$. distasonis HMP-1 has a polarity index of $1.59\left(1.56\right.$ for the $100^{\circ} \mathrm{C}$ form $)$, which indicates a protein of intermediate polarity with a slightly less polar nature than the heat-modifiable protein from the Fusobacterium $\mathrm{sp}^{{ }^{41}}$ We were unable to obtain an Nterminal sequence of this protein because the $\mathrm{N}$ terminus was blocked.

Radio-iodination of $B$. distasonis cell-surface-exposed proteins

The procedure used labels only cell-surface-exposed proteins because the iodinating enzyme is covalently attached to a latex bead. After iodination, the cell pellet was washed several times to remove excess unbound ${ }^{125} \mathrm{I}$, as well as any extraneous proteins that may have been released from lysed cells. Whole cells of $B$. distasonis were labelled with ${ }^{125} \mathrm{I}$ and then processed for purification of the HMP-1 protein. In the crude cell-envelope fraction, the major protein species labelled migrated at $>200 \mathrm{kDa}$ when solubilised at $25^{\circ} \mathrm{C}$ (fig. 5, lane 1). At $100^{\circ} \mathrm{C}$, the major band observed migrated at c. $95 \mathrm{kDa}$ and another strong band was observed at c. $55 \mathrm{kDa}$ (lane 2). Numerous other faint bands were observed. In the Triton pellet (i.e., OMenriched fraction) numerous bands were observed, including those mentioned above. Additionally, the HMP-1 band (i.e., $38 \mathrm{kDa}$ at $25^{\circ} \mathrm{C}$ and $45 \mathrm{kDa}$ at $100^{\circ} \mathrm{C}$ ) was seen clearly, indicating that at least part of the protein was exposed on the outer surface (lanes 3 and 4). In the SDS pellet solubilised at $25^{\circ} \mathrm{C}$, the band of $>200 \mathrm{kDa}$ was the main band labelled, and the 
Table I. Amino-acid composition of electro-eluted $B$. distasonis $\mathrm{HMP}-138 \mathrm{kDa}\left(25^{\circ} \mathrm{C}\right)$ band, solubilised at $25^{\circ} \mathrm{C}$ or $100^{\circ} \mathrm{C}$ and re-run in SDS-PAGE

\begin{tabular}{|c|c|c|c|c|}
\hline \multirow{2}{*}{$\begin{array}{l}\text { Amino } \\
\text { acid }\end{array}$} & \multicolumn{2}{|c|}{$\begin{array}{l}\text { 38-kDa }\left(25^{\circ} \mathrm{C}\right) \\
\text { form }\end{array}$} & \multicolumn{2}{|c|}{$\begin{array}{l}45-\mathrm{kDa}\left(100^{\circ} \mathrm{C}\right) \\
\text { form }\end{array}$} \\
\hline & $\begin{array}{l}\text { Number of } \\
\text { residues }\end{array}$ & Mol \% & $\begin{array}{l}\text { Number of } \\
\text { residues }\end{array}$ & Mol \% \\
\hline \multicolumn{5}{|c|}{ Neutral aliphatic } \\
\hline Gly & 31 & $13 \cdot 6$ & 54 & $14 \cdot 0$ \\
\hline Ala & 29 & $12 \cdot 7$ & 39 & $10 \cdot 1$ \\
\hline Val & 14 & 6.1 & 24 & 6.2 \\
\hline Leu & 14 & $6 \cdot 1$ & 28 & $7 \cdot 2$ \\
\hline Lle & 8 & 3.5 & 15 & 3.9 \\
\hline Ser & 13 & 5.7 & 20 & $5 \cdot 2$ \\
\hline Thr & 10 & $4 \cdot 4$ & 16 & $4 \cdot 1$ \\
\hline \multicolumn{5}{|l|}{ Aromatic } \\
\hline Phe & 11 & 4.8 & 20 & $5 \cdot 2$ \\
\hline Tyr & 8 & 3.5 & 19 & 4.9 \\
\hline \multicolumn{5}{|c|}{ Sulphur-containing } \\
\hline Cys & 0 & 0.0 & 0 & 0.0 \\
\hline Met & 5 & $2 \cdot 2$ & 2 & 0.5 \\
\hline \multicolumn{5}{|l|}{ Imino- } \\
\hline Pro & 9 & 3.9 & 17 & $4 \cdot 4$ \\
\hline \multicolumn{5}{|c|}{ Dicarboxylic } \\
\hline Asp & 25 & 11.0 & 45 & 11.6 \\
\hline Glu & 28 & $12 \cdot 3$ & 46 & 11.9 \\
\hline \multicolumn{5}{|l|}{ Basic } \\
\hline His & 2 & 0.9 & 4 & 1.0 \\
\hline Arg & 11 & $4 \cdot 8$ & 22 & $5 \cdot 7$ \\
\hline Lys & 10 & $4 \cdot 4$ & 16 & $4 \cdot 1$ \\
\hline
\end{tabular}

HMP-1 (38-kDa) band was seen clearly (lane 5). A strong band was observed also at $25 \mathrm{kDa}$ (lane 5). When the sample was solubilised at $100^{\circ} \mathrm{C}$, the major bands seen migrated at 95, 66, 55, 45 (HMP-1) and $35 \mathrm{kDA}$ (lane 6). The SDS pellet was also separately labelled and analysed as a control, to ensure that the HMP-1 protein could be labelled by this procedure (lanes 7 and 8).
Table II. Polarity (sum mol\% of polar amino acids ${ }^{31}$ ) of electro-eluted $B$. distasonis HMP-1 $38-\mathrm{kDa}\left(25^{\circ} \mathrm{C}\right)$ band solubilised at $25^{\circ} \mathrm{C}$ or $100^{\circ} \mathrm{C}$

\begin{tabular}{|c|c|c|c|}
\hline \multirow{3}{*}{$\begin{array}{l}\text { Amino } \\
\text { acid }\end{array}$} & \multicolumn{3}{|c|}{ Mol \% of polar amino acids in } \\
\hline & \multicolumn{2}{|c|}{ B. distasonis HMP-1 } & \multirow{2}{*}{$\begin{array}{c}\text { F. nucleatum } \\
\text { ATCC } 25586 \\
\text { heat-modifiable } \\
\text { protein }^{41}\end{array}$} \\
\hline & $\begin{array}{c}38-\mathrm{kDa} \\
\left(25^{\circ} \mathrm{C}\right) \text { form }\end{array}$ & $\begin{array}{c}45-\mathrm{kDa} \\
\left(100^{\circ} \mathrm{C}\right) \text { form }\end{array}$ & \\
\hline Asp & 11 & $11 \cdot 6$ & 11.5 \\
\hline Glu & $12 \cdot 3$ & 11.9 & $13 \cdot 3$ \\
\hline Lys & 4.4 & $4 \cdot 1$ & 6.8 \\
\hline Ser & $5 \cdot 7$ & $5 \cdot 2$ & 10.5 \\
\hline Arg & 4.8 & 5.7 & $2 \cdot 8$ \\
\hline Thr & 4.4 & $4 \cdot 1$ & 5.9 \\
\hline His & 0.9 & 1.0 & $2 \cdot 4$ \\
\hline Polarity & $43 \cdot 5 \%$ & $43.6 \%$ & $53 \cdot 2 \%$ \\
\hline
\end{tabular}

Cross-reactivity with membrane proteins from E. coli

The antisera reacted as expected with OM preparations from $E$. coli $\mathrm{K} 12$, but did not react with the $B$. distasonis $\mathrm{OM}$ preparations (unpublished data). The anti-OmpA serum reacted with the $E$. coli preparation, staining bands at 28 and $33 \mathrm{kDA}$ for preparations solubilised at $25^{\circ} \mathrm{C}$ and $100^{\circ} \mathrm{C}$, respectively; these are the expected mol. wts for $E$. coli OmpA.42 The antiporin antiserum stained one band at $35 \mathrm{kDa}$ with $E$. coli preparations solubilised at $100^{\circ} \mathrm{C}$ (the approximate expected location for $E$. coli porin ${ }^{4}$ ), but did not react with the $B$. distasonis $\mathrm{OM}$ preparation. The $E$. coli porin forms aggregates at $25^{\circ} \mathrm{C}$ and does not enter the gel under these conditions.

Pore-forming ability of the partially purified $B$. distasonis HMP-1

The dialysed and concentrated OG-supernate frac-

Table III. Polarity index (ratio of polar to apolar amino acids ${ }^{30}$ ) of electroeluted $B$. distasonis HMP-1 $38-\mathrm{kDa}\left(25^{\circ} \mathrm{C}\right)$ band solubilised at $25^{\circ} \mathrm{C}$ or $100^{\circ} \mathrm{C}$

\begin{tabular}{|c|c|c|c|}
\hline \multirow{3}{*}{$\begin{array}{l}\text { Amino } \\
\text { acid }\end{array}$} & \multicolumn{3}{|c|}{ Number of amino-acid residues in } \\
\hline & \multicolumn{2}{|c|}{ B. distasonis HMP-1 } & \multirow{2}{*}{$\begin{array}{l}\text { F. nucleatum ATTC } 25586 \\
\text { heat-modifiable protein }\end{array}$} \\
\hline & $\begin{array}{c}38-\mathrm{kDa} \\
\left(25^{\circ} \mathrm{C}\right) \text { form }\end{array}$ & $\begin{array}{c}45-\mathrm{kDa} \\
\left(100^{\circ} \mathrm{C}\right) \text { form }\end{array}$ & \\
\hline \multicolumn{4}{|l|}{ Polar } \\
\hline Asp & 25 & 45 & $11 \cdot 5$ \\
\hline Glu & 28 & 46 & $13 \cdot 3$ \\
\hline Lys & 10 & 16 & $6 \cdot 8$ \\
\hline Ser & 13 & 20 & $10 \cdot 5$ \\
\hline Arg & 11 & 22 & $2 \cdot 8$ \\
\hline Thr & 10 & 16 & $5 \cdot 9$ \\
\hline Total & 97 & 165 & 50.8 \\
\hline \multicolumn{4}{|l|}{ Apolar } \\
\hline Val & 14 & 24 & $5 \cdot 5$ \\
\hline Leu & 14 & 28 & 7 \\
\hline Ile8 & 8 & 15 & $4 \cdot 3$ \\
\hline Met & 5 & 2 & $1 \cdot 1$ \\
\hline Pro & 9 & 17 & 5 \\
\hline Phe & 11 & 20 & 3.4 \\
\hline Total & 61 & 106 & $26 \cdot 3$ \\
\hline Polarity index & $1 \cdot 59$ & 1.56 & 1.93 \\
\hline
\end{tabular}




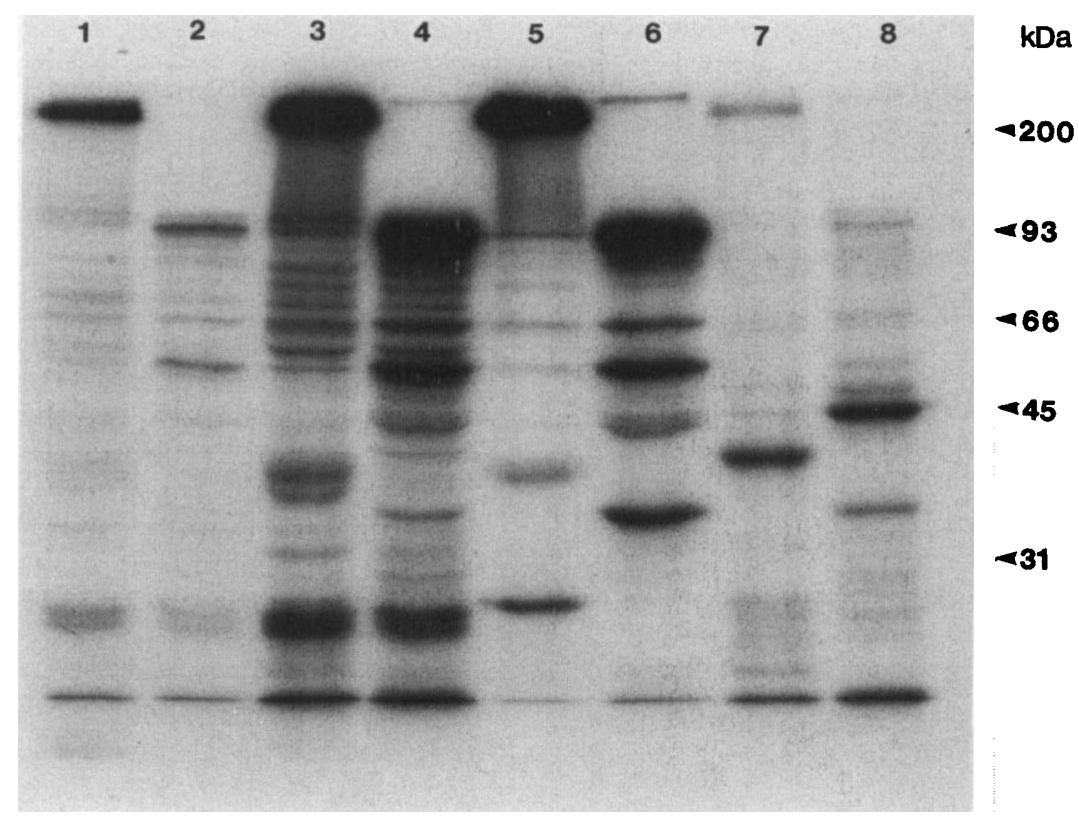

Fig. 5. Autoradiograph of SDS-PAGE gel of radio-iodinated cell-surface proteins of $B$. distasonis: lane 1 , cell envelope $\left(25^{\circ} \mathrm{C}\right) ; 2$, cell envelope $\left(100^{\circ} \mathrm{C}\right) ; 3$, Triton pellet (crude OMP) $\left(25^{\circ} \mathrm{C}\right) ; 4$, Triton pellet (crude OMP) $\left(100^{\circ} \mathrm{C}\right) ; 5$, SDS pellet $\left(25^{\circ} \mathrm{C}\right) ; 6$, SDS pellet $\left(100^{\circ} \mathrm{C}\right)$; 7 , radio-iodinated SDS pellet $\left(25^{\circ} \mathrm{C}\right) ; 8$, radio-iodinated SDS pellet $\left(100^{\circ} \mathrm{C}\right)$.

Table IV. Pore-forming activity of $B$. distasonis HMP-1 fraction in liposomes

\begin{tabular}{|c|c|c|c|c|c|}
\hline Preparation & $\begin{array}{l}\text { Protein } \\
\text { added } \\
(\mu \mathrm{g})\end{array}$ & Sugar & $\Delta O D_{\min }$ & $\underset{\mathrm{dt}^{*}}{\mathrm{~d}(1 / \mathrm{OD}) /}$ & $\begin{array}{l}\text { Permeability } \\
\text { rate } \dagger(\%)\end{array}$ \\
\hline B. distasonis & 20 & Arabinose & 0.19 & 0.725 & 100 \\
\hline \multirow{6}{*}{ HMP-1 } & & Glucose & 0.13 & 0.50 & 69 \\
\hline & & N-Ac-Gluł & $0 \cdot 10$ & 0.332 & 45 \\
\hline & & Stachyose & 0.005 & 0.022 & $3 \cdot 1$ \\
\hline & 190 & Maltose & 0.24 & 0.28 & $22 \S$ \\
\hline & & Sucrose & 0.19 & 0.207 & $16 \cdot 5 \S$ \\
\hline & & Stachyose & 0.04 & 0.043 & $3.4 \S$ \\
\hline $\begin{array}{l}\text { Heat-treated HMP-1 } \\
\text { (negative control) }\end{array}$ & 80 & Arabinose & 0.015 & 0.017 & $8.9 \|$ \\
\hline \multirow{5}{*}{$\begin{array}{l}E \text {. coli } \mathrm{K}-12 \\
\text { crude OMP }\end{array}$} & 40 & Arabinose & 0.43 & 0.806 & 100 \\
\hline & & Glucose & 0.335 & 0.655 & 81 \\
\hline & & N-Ac-Glu & 0.225 & 0.428 & 53 \\
\hline & & Maltose & 0.06 & 0.112 & 14 \\
\hline & & Sucrose & 0.03 & 0.04 & $5 \cdot 0$ \\
\hline
\end{tabular}

* $\mathrm{d}(1 / \mathrm{OD}) / \mathrm{dt}$ was calculated from the formula $\left[1 /(\mathrm{OD})^{2}\right] \times[\mathrm{d}(\mathrm{OD} / \mathrm{dt}]$, see Results.

$\dagger$ Relative to arabinose.

$\ddagger \mathrm{N}$-acetyl-D-glucosamine.

$\S$ Normalised to arabinose in liposomes prepared with $190 \mu \mathrm{g}$ of protein with the proportional swelling rates in arabinose for both protein concentrations as a correction factor.

II Normalised to arabinose with $80 \mu \mathrm{g}$ of the same preparation of HMP-1 without heat treatment.

tion (fig. 1, lane 9) containing the $B$. distasonis HMP1 isolated to near homogeneity (but not completely pure) was incorporated into liposomes and tested for pore-forming ability. In this assay, phospholipid liposomes were prepared containing pore-forming molecules within the bilayer membrane and an impermeable solute (in this case Dextran T-40) in the intravesicular space. When these vesicles are diluted in an isotonic solution with a test solute (i.e., the various sugars), the influx of the test solute into the liposome is followed by a rapid influx of water, and the liposomes swell, reducing their turbidity. The permeability of the channel is assumed to be proportional to the initial swelling rate, which is proportional to $\mathrm{d}(1 / \mathrm{OD}) / \mathrm{dt}^{7}$ The formula, $d[1 / \mathrm{OD}] \mathrm{dt}=\left[1 /(\mathrm{OD})^{2}\right] \times[\mathrm{d}(\mathrm{OD}) / \mathrm{dt}]$ was used to calculate the initial swelling rate ${ }^{34}$ (where OD was the initial turbidity of the suspension, and $\mathrm{d}(\mathrm{OD}) / \mathrm{dt}$ was the initial slope of the OD versus time tracing). The swelling rates of the sugars were calculated as relative permeability rates compared to the swelling rate of arabinose $(100 \%)$.

The results of the liposome swelling assays are listed in table IV. Because the rate was too low to be measured for sucrose and maltose when $20 \mu \mathrm{g}$ of $B$. 
distasonis protein was used, the assays were repeated with $190 \mu \mathrm{g}$ of protein, and the values were normalised by applying the proportional swelling rates in arabinose for both protein concentrations as a correction factor. ${ }^{7}$ In most assays, $20 \mu \mathrm{g}$ of OG-supernate fractions (i.e., partially purified HMP-1) was used. The permeability coefficients for $2 \mu \mathrm{g}$ and $10 \mu \mathrm{g}$ of $\mathrm{OG}$ supernate were 0.01 and 0.065 , respectively. Assays were performed with $E$. coli protein for comparison, and to serve as positive controls of the liposome preparation. For the $E$. coli sample, $40 \mu \mathrm{g}$ of crude OMP (Triton pellet) was used. The rates of change of $\mathrm{OD}_{400}$ were slower for the liposomes with $B$. distasonis protein than for those with $E$. coli K12 OMP. As expected, the higher mol. wt disaccharides (maltose and sucrose) had much lower permeability rates than the smaller monosaccharides. Stachyose (mol. wt 666.6) should not penetrate the pores, and was used to determine the iso-osmolar concentration for the assay. OG-supernate fractions incubated at $100^{\circ} \mathrm{C}$ for $10 \mathrm{~min}$ and then incorporated into liposomes served as negative controls, and the permeability rate of arabinose for boiled preparations was $<9 \%$ of the rate for the unboiled sample, confirming the specific protein nature of the pore-forming molecules. The pore radius was not calculated in this study because the preparations used were not completely pure, and it was possible that one or more of the contaminating proteins could have contributed to the pore formation. Electro-eluted preparations of the HMP- $125^{\circ} \mathrm{C}$ band were treated as follows to remove the SDS: (1) passed through an Extracti-gel column (Pierce Chemical Co.); (2) treated by acetone precipitation alone; or (3) treated by acetone precipation and renaturation by dilution in guanidine- $\mathrm{HCl}$ as described by Hager and Burgess. ${ }^{29}$ None of these preparations was active in the liposome assay.

\section{Discussion}

In $E$. coli, the mobility of the major heat-modifiable OMP, OmpA, is less when solubilised at $100^{\circ} \mathrm{C}$ than at $25^{\circ} \mathrm{C}^{39}$ Antiserum to the $E$. coli $\mathrm{K} 12$ OmpA crossreacted with the heat-modifiable proteins from all strains of Enterobacteriaceae tested in one study. ${ }^{43}$ Because these heat-modifiable proteins were nearly identical in primary structure, the authors suggest that the structure, and perhaps the function, of the heatmodifiable protein is strongly conserved in Enterobacteriaceae. Proteins with similar heat-modifiable behaviour have been described in other Gram-negative bacteria. ${ }^{43-45}$

The E. coli OmpA protein is not thought to produce transmembrane channels ${ }^{46}$ and is not thought to be important in antibiotic resistance, although recent reports have described pore-forming proteins that exhibit this particular heat-modifiable behaviour. ${ }^{38,47}$ The role of porins in the permeability of gram-negative aerobic bacteria and in antimicrobial resistance has been extensively studied ${ }^{11,37,48-51}$ and recently reviewed. $^{9,16}$ Diminished uptake of, and increased resistance to, particular antibiotics was seen in several species of bacteria with altered or missing porin molecules. ${ }^{11,50-52}$

In anaerobic bacteria, the role of permeability barriers in antibiotic resistance has been approached only indirectly ${ }^{53,54}$ and no porin molecules have been identified in the $B$. fragilis group. Indeed, little is known about the structure and function of OMPs in anaerobes. Ionic charge, hydrophobicity, and mol. wt may influence $\beta$-lactam uptake across the $B$. fragilis OM. ${ }^{18}$ Both $\beta$-lactamase and a permeability barrier have been shown to affect the activity of cephalosporins against members of the $B$. fragilis group, except for $B$. distasonis, which showed only a permeability barrier to all antibiotics tested. ${ }^{24}$

$F$. nucleatum is a gram-negative anaerobic bacterium commonly isolated from oral infections. Recently, Takada $e t$ al. ${ }^{55}$ reported the isolation from $F$. nucleatum of a heat-modifiable protein with pore-forming activity. The protein was collected from a Sephacryl S200 column, dialysed and repeatedly acetoneprecipitated to remove remaining detergent and then used in a liposome assay. In our experience, acetone precipitation destroyed the functional activity of our preparation, even when done in a procedure designed to restore some functional activity. ${ }^{29}$ Electroelution may also have destroyed functional activity of our protein. The mol. wt of the porin fraction of Takada et al. ${ }^{55}$ was $37 \mathrm{kDa}$ when solubilised without boiling, and $41 \mathrm{kDa}$ when boiled before electrophoresis. The fraction contained lipopolysaccharide and showed strong immunobiological activity.

In other studies, heat-modifiable proteins of 38$50 \mathrm{kDa}$ were isolated from the OM of $F$. nucleatum $^{35,41,56}$ that seem to be remarkably similar to our HMP-1 protein. Bakken et al. ${ }^{41}$ were unsuccessful in purifying the individual protein species from SDS solutions by gel chromatography unless proteins were first maleylated. This fusobacterium protein has been termed HM-1 (for heat-modifiable protein 1). ${ }^{35,41,56}$ HM-1 is strongly bound to the matrix, although whether it is complexed with lipopolysaccharide ${ }^{55}$ or peptidoglycan ${ }^{56}$ is not clear. A heat-modifiable protein from $F$. nucleatum has also been implicated as a coaggregation receptor with Streptococcus sanguis, ${ }^{57}$ although the amino-acid analysis suggests that it may be a different protein from that described by Bakken $e t$ $a l^{41}$

We investigated the OM components of $B$. distasonis because, amongst the $B$. fragilis group, it is one of the most resistant to $\beta$-lactam antibiotics, yet it has one of the highest proportions of $\beta$-lactamase-negative strains. Thus, there must be some other resistance mechanism, such as altered targets, altered OM permeability characteristics, or low (undetectable) levels of $\beta$-lactamase combined with altered permeability. The strain used in this study was previously used to study changes in penicillin-binding proteins (PBP) of a 
laboratory-induced cefoxitin-resistant mutant. ${ }^{58}$ The strain was chosen because it did not produce $\beta$ lactamase, which made it a good candidate for producing drug-resistant mutants in a study of nonenzyme-mediated mechanisms of resistance. We found changes in the pattern of the PBP-1 protein that correlated with cefoxitin resistance but were not able to identify any OM changes. ${ }^{58}$ Piddock and Wise ${ }^{59}$ found two cefoxitin-resistant clinical isolates that showed OMP changes - an apparent lack of the 49-50$\mathrm{kDa}$ protein and reduced affinity of PBPs for cefoxitin. In another study, no correlation between OM permeation and MICs of the cephalosporins was found in sensitive $B$. fragilis parental strains and mutants resistant to ceftezole, cefazolin and cephalothin..$^{60}$

This study is the first report of a heat-modifiable OMP in Bacteroides spp., and the first report of porin activity in a bacteroides $\mathrm{OM}$ fraction. The $B$. distasonis HMP-1 protein exhibits a heat-modifiable behaviour in SDS gels similar to that of the $E$. coli OmpA protein, and is exposed on the outer surface of the cell. Like the pore-forming fractions in F. nucleatum ${ }^{55}$ and the two Campylobacter species, ${ }^{47}$ a pore-forming fraction isolated from the $B$. distasonis $\mathrm{OM}$ is primarily composed of a protein species with the heat-modifiable character of the $E$. coli OmpA molecule. Although the OmpA molecule is thought to be highly conserved, and crossreactivity between OmpAs of various gram-negative aerobic enteric bacteria has been demonstrated, ${ }^{43}$ the HMP-1 of $B$. distasonis did not cross-react with antiserum prepared against an $E$. coli OmpA, nor with

\section{References}

1. Nikaido H, Vaara M. Outer membrane. In: Neidhardt FC, Ingraham JL, Low KB et al. (eds) Escherichia coli and Salmonella typhimurium: cellular and molecular biology, vol 1. Washington, DC, American Society for Microbiology. 1987: 7-22.

2. Inouye $\mathbf{M}$ (ed). Bacterial outer membranes as model systems. New York, John Wiley and Sons. 1987.

3. Rosenbusch JP. Structural and functional properties of porin channels in E. coli outer membranes. Experientia 1990; 46: 167-173.

4. Rosenbusch JP. Characterization of the major envelope protein from Escherichia coli. J Biol Chem 1974; 249: 8019-8029.

5. Garavito RM, Rosenbusch JP. Isolation and crystallization of bacterial porin. Methods Enzymol 1986; 125: 309-328.

6. Nikaido $H$. Structure and functions of the cell envelope of gram-negative bacteria. Rev Infect Dis 1988; 10 Suppl 2: S279-S281.

7. Nikaido H, Rosenberg EY. Porin channels in Escherichia coli: studies with liposomes reconstituted from purified proteins. $J$ Bacteriol 1983; 153: 241-252.

8. Nikaido H, Rosenberg EY, Foulds J. Porin channels in Escherichia coli: studies with $\beta$-lactams in intact cells. $J$ Bacteriol 1983; 153: 232-240.

9. Nikaido $H$. Outer membrane barrier as a mechanism of antimicrobial resistance. Antimicrob Agents Chemother 1989; 33: 1831-1836.

10. Piddock LJ, Wise $R$. Newer mechanisms of resistance to betalactam antibiotics in gram-negative bacteria. $J$ Antimicrob Chemother 1985; 16: 279-284.

11. Harder KJ, Nikaido H, Matsuhashi M. Mutants of Escherichia coli that are resistant to certain beta-lactam compounds lack the ompF porin. Antimicrob Agents Chemother 1981; 20: $549-552$. an antiserum to $E$. coli porin. This does not preclude the possibility that some antigenic similarity might be demonstrated with other antisera. OM preparations were made from the nine ATCC type strains of the $B$. fragilis group, and all had proteins of approximately the same size with heat modifiable behaviour similar to that of the $B$. distasonis HMP-1 (unpublished data).

Little is known about the function of the OMPs in anaerobic bacteria, or their importance in antimicrobial resistance. The expanding use of $\beta$-lactamase-stable antibiotics will probably result in the selection of anaerobic bacteria of the $B$. fragilis group able to survive the antibiotic challenge due to changes in PBPs and OM permeability characteristics. There is increasing recognition that interaction of a cell wall barrier and $\beta$-lactamase activity may result in highlevel resistance to $\beta$-lactam antibiotics. ${ }^{9,61}$ Understanding the role of permeability barriers in antimicrobial resistance and in cell metabolism in general will require isolation and characterisation of OMPs, including pore-forming molecules, and elucidation of their structure and function.

This work was supported in part by Veterans Administration Medical Research funds and in part by Pfizer Pharmaceuticals (New York, NY) and SmithKline Beecham Pharmaceuticals (Philadelphia, PA). Amino-acid composition was determined at the University of California Protein Microsequencing Facility, Los Angeles, CA. This facility was aided by a BRS Shared instrumentation Grant 1 S10RR05554-01 from the National Institutes of Health. We are grateful to Dr H. Nikaido and Ms E. Rosenberg (University of California, Berkeley, CA) for their advice, training and encouragement.

12. Medeiros AA, O'Brien TF, Rosenberg EY, Nikaido H. Loss of OmpC porin in a strain of Salmonella typhimurium causes increased resistance to cephalosporins during therapy. $J$ Infect Dis 1987; 156: 751-757.

13. Hancock REW, Nikaido $H$. Outer membranes of gram-negative bacteria. XIX. Isolation from Pseudomonas aeruginosa PA01 and use in reconstitution and definition of the permeability barrier. $J$ Bacteriol 1978 ; 136: 381-390.

14. Yoshimura $F$, Nikaido $H$. Diffusion of $\beta$-lactam antibiotics through the porin channels of Escherichia coli K-12. Antimicrob Agents Chemother 1985; 27 : 84-92.

15. Nikaido $\mathbf{H}$. Bacterial resistance to antibiotics as a function of outer membrane permeability. $J$ Antimicrob Chemother 1988 ; 22 Suppl A: 17-22.

16. Nikaido $H$. Role of permeability barriers in resistance to betalactam antibiotics. Pharmacol Ther 1985; 27 : 197-231.

17. Cuchural GJ, Tally FP, Jacobus NV, Marsh PK, Mayhew JW Cefoxitin inactivation by Bacteroides fragilis. Antimicrob Agents Chemother 1983; 24: 936-940.

18. Cuchural GJ, Hurlbut S, Malamy MH, Tally FP. Permeability to beta-lactams in Bacteroides fragilis. J Antimicrob Chemother $1988 ; 22$ : 785-790.

19. Eley A, Greenwood D. Beta-lactamases of type culture strains of the Bacteroides fragilis group and of strains that hydrolyse cefoxitin, latamoxef and imipenem. $J \mathrm{Med}$ Microbiol 1986; 21 : 49-57.

20. Yotsuji A, Minami S, Inoue M, Mitsuhashi S. Properties of novel $\beta$-lactamase produced by Bacteroides fragilis. Antimicrob Agents Chemother 1983; 24: 925-929.

21. Finegold SM. General aspects of anaerobic infections. In Finegold SM, George WL (eds) Anaerobic infections in humans. San Diego, Academic Press. 1989: 137-153.

22. Diedrich DL, Martin AE. Outer membrane proteins of the Bacteroides fragilis group. Curr Microbiol 1981; 6: 85-88.

23. Kotarski SF, Salyers AA. Isolation and characterization of 
outer membranes of Bacteroides thetaiotaomicron grown on different carbohydrates. J Bacteriol 1984; 158: 102-109.

24. Malouin F, Lamothe F. The role of beta-lactamase and the permeability barrier on the activity of cephalosporins against members of the Bacteroides fragilis group. Can J Microbiol 1987; 33: 262-266.

25. Holdemann LV, Cato EP, Moore WEC. Anaerobe laboratory manual, 4th edn. Blacksburg, VA, Virginia Polytechnic Institute and State University. 1977.

26. Sutter VL, Citron DM, Edelstein MAC, Finegold SM. Wadsworth anaerobic bacteriology manual, 4th edn. Belmont, CA, Star Publishing Co. 1985.

27. Varel VH, Bryant MP. Nutritional features of Bacteroides fragilis subsp. fragilis. Appl Microbiol 1974; 28: 251-257.

28. Laemmli UK, Favre M. Maturation of the head of bacteriophage T4. DNA packaging events. J Mol Biol 1973; 80: $575-599$.

29. Hager DA, Burgess RR. Elution of proteins from sodium dodecyl sulfate-polyacrylamide gels, removal of sodium dodecyl sulfate, and renaturation of enzymatic activity results with sigma subunit of Escherichia coli RNA polymerase, wheat germ DNA topoisomerase, and other enzymes. Anal Biochem 1980; 109: 76-86.

30. Hatch FT. Correlation of amino-acid composition with certain characteristics of proteins. Nature 1965; 206: 777-779.

31. Capaldi RA Vanderkooi G. The low polarity of many membrane proteins. Proc Natl Acad Sci USA 1972; 69: 930-932.

32. Tsang VCW, Peralta JM, Simons AR. Enzyme-linked immunoelectrotransfer blot techniques (EITB) for studying the specificities of antigens and antibodies separated by gel electrophoresis. Methods Enzymol 1983; 92: 377-391.

33. Nikaido H. Rosenberg EY. Effect of solute size on diffusion rates through the transmembrane pores of the outer membranes of Escherichia coli. J Gen Physiol 1981; 77: 121-135.

34. Nikaido $H$. Proteins forming large channels from bacterial and mitochondrial outer membranes: porins and phage lambda receptor proteins. In: Fleischer S, Fleischer B (eds) Methods in enzymology, vol 97, Biomembranes. New York, Academic Press. 1983: 85-100.

35. Bakken V, Jensen HB. Outer membrane proteins of Fusobacterium nucleatum Fev1. J Gen Microbiol 1986; 132 1069-1078.

36. Schnaitman CA. Solubilization of the cytoplasmic membrane of Escherichia coli by Triton X-100. J Bacteriol 1971; 108: 545-552.

37. Mitsuyama J, Hiruma R, Yamaguchi A, Sawai T. Identification of porins in outer membranes of Proteus, Morganella, and Providencia spp. and their role in outer membrane permeation of $\beta$-lactams. Antimicrob Agents Chemother 1987; 31: 379-384.

38. Hancock REW, Decad GM, Nikaido H. Identification of the protein producing transmembrane diffusion pores in the outer membrane of Pseudomonas aeroginosa PA01. Biochim Biophys Acta 1979; 554: 323-331.

39. Nakamura H, Mizushima S. Effects of heating in dodecyl sulfate solution on the conformation and electrophoretic mobility of isolated major outer membrane proteins from Escherichia coli K12. J Biochem 1976; 80: 1411-1422.

40. McMichael JC, Ou JT. Metal ion dependence of a heatmodifiable protein from the outer membrane of Escherichia coli upon sodium dodecyl sulfate-gel electrophoresis. $J$ Bacteriol 1977; 132: 314-320.

41. Bakken V, Aarø S, Jensen HB. Purification and partial characterization of a major outer-membrane protein of Fusobacterium nucleatum. J Gen Microbiol 1989 135: 32533262.

42. Schweizer M, Hindennach, I, Garten W, Henning U. Major proteins of the Escherichia coli outer cell envelope mem- brane. Interaction of Protein II with lipopolysaccharide. Eur J Biochem 1978; 82: 211-217.

43. Beher MG, Schnaitman CA, Pugsley AP. Major heat-modifiable outer membrane protein in gram-negative bacteria: comparison with the OmpA protein of Escherichia coli. $J$ Bacteriol 1980; 143: 906-913.

44. Frasch CE, Mocca LF. Heat-modifiable outer membrane proteins of Neisseria meningitidis and their organization within the membrane. $J$ Bacteriol 1978; 136: 1127-1134.

45. Verstreate DR, Creasy MT, Caveney NT, Balswin CL, Blab MW, Winter AJ. Outer membrane proteins of Brucella abortus: isolation and characterization. Infect Immun 1982 35: $979-989$.

46. Nikaido $H$, Vaara $M$. Molecular basis of bacterial outer membrane permeability. Microbiol Rev 1985; 49: 1-32.

47. Page WJ, Huyer G, Huyer M, Worobec EA. Characterization of the porins of Campylobacter jejuni and Campylobacter coli and implications for antibiotic susceptibility. Antimicrob Agents Chemother 1989 33: 297-303.

48. Büscher KH, Cullmann W, Dick W, Wendt S, Opferkuch W. Imipenem resistance in Pseudomonas aeroginosa is due to diminished expression of outer membrane proteins. J Infect Dis 1987; 156: 681-684.

49. Parr TR, Moore RA, Moore LV, Hancock REW. Role of porins in intrinsic antibiotic resistance of Pseudomonas cepacia. Antimicrob Agents Chemother 1987; 31: 121-123.

50. Sawai T, Hiruma R, Kawana N, Kaneko M, Taniyasu F, Inam A. Outer membrane permeation of $\beta$-lactam antibiotics in Escherichia coli, Proteus mirabilis, and Enterobacter cloacae. Antimicrob Agents Chemother 1982; 22: 585-592.

51. Trias J, Dufresne J, Levesque RC, Nikaido H. Decreased outer membrane permeability in imipenem-resistant mutants of Pseudomonas aeruginosa. Antimicrob Agents Chemother 1989; 33: 1201-1206.

52. Godfrey AJ, Bryan LE. Penetration of $\beta$-lactams through Pseudomonas aeruginosa porin channels. Antimicrob Agents Chemother 1987; 31: 1216-1221.

53. Crosby MA, Gump DW. Activity of cefoperazone and two $\beta$ lactamase inhibitors, sulbactam and clavulanic acid, against Bacteroides spp. correlated with $\beta$-lactamase production. Antimicrob Agents Chemother 1982; 22: 398-405.

54. Olsson B, Dornbusch $\mathrm{K}$, Nord CE. Factors contributing to resistance to beta-lactam antibiotics in Bacteroides fragilis. Antimicrob Agents Chemother 1979; 15: 263-268.

55. Takada H, Ogawa T, Yoshimura F et al. Immunological activities of a porin fraction isolated from Fusobacterium nucleatum ATCC 10953. Infect Immun 1988; 56: 855-863.

56. DiRienzo JM, Rosan B. Isolation of a major cell envelope protein from Fusobacterium nucleatum. Infect Immun 1984; 44: 386-393.

57. Kaufman J, DiRienzo JM. Isolation of a corncob (coaggregation) receptor polypeptide from Fusobacterium nucleatum. Infect Immun 1989; 57: 331-337.

58. Wexler H, Halebian S. Alterations to the penicillin-binding proteins in the Bacteroides fragilis group; a mechanism for non- $\beta$-lactamase mediated cefoxitin resistance. $J$ Antimicrob Chemother 1990; 26: 7-20.

59. Piddock LJV, Wise R. Cefoxitin resistance in Bacteroides species: evidence indicating two mechanisms causing decreased susceptibility. J Antimicrob Chemother 1987; 19: 161-170.

60. Albert MJ, Rajan DP, Mathan VI. In vitro susceptibility to metronidazole of bacteria from the small intestine of tropical sprue patients. Ind J Med Res 1984; 79: 333-336.

61. Jarlier V, Gutmann L, Nikaido H. Interplay of cell wall barrier and $\beta$-lactamase activity determines high resistance to $\beta$ lactam antibiotics in Mycobacterium chelonae. Antimicrob Agents Chemother 1991; 35: 1937-1939. 